\section{Goran Milovanović ${ }^{1}$}

Faculty of Economics, University of Niš

Goran Radisavljević ${ }^{2}$

Financial Advisor, Municipality of Sokobanja

\section{Gordana Đukić ${ }^{3}$}

Faculty of Economics, University of Belgrade
ORIGINAL SCIENTIFIC ARTICLE doi:10.5937/ekonomika1802033M

Received December, 11, 2017

Accepted: March, 15, 2018

\title{
DEPENDENCE OF SERBIAN ECONOMIC DEVELOPMENT ON FOREIGN DIRECT INVESTMENT FLOWS
}

\begin{abstract}
The aim of the paper is to identify, based on the analysis of relevant theoretical findings, the effects of foreign direct investment (FDI) on economic development and export growth of the Republic of Serbia. First, the characteristics of global FDI flows are presented. What follows is the analysis of FDI flows in the Republic of Serbia in the period from 2006 to 2016, and assessment of their real long-term effects. Finally, the relationship between FDI and export of the Republic of Serbia is examined.
\end{abstract}

Key words: foreign direct investment, gross domestic product, globalization, economic development, export

JEL classification: 016,052, G20

\section{ЗАВИСНОСТ ЕКОНОМСКОГ РАЗВОЈА СРБИЈЕ ОД ТОКА СТРАНИХ ДИРЕКТНИХ ИНВЕСТИЦИЈА}

\begin{abstract}
Апстракт
Циљ рада је да на основу анализе релевантних теоријских налаза утврди ефекте страних директних инвестиција (СДИ) на економски развој и раст извоза Републике Србије. Прво су представљене карактеристике глобалних токова СДИ. Следи анализа токова СДИ у Републици Србији у периоду од 2006. до 2016. године и процена њихових реалних дугорочних ефеката. На крају, разматра се однос између СДИ и извоза Републике Србије.
\end{abstract}

Кључне речи: директне стране инвестиције, бруто домаћи производ, глобализација, економски развој, извоз.

\footnotetext{
${ }^{1}$ goran.milovanović@eknfak.ni.ac.rs

${ }^{2}$ radisavljevic.goran1964@gmail.com

33ordanadkc048@gmail.com
} 


\section{Introduction}

Foreign direct investment (FDI) has become one of the most important factors in global economic development over the last few decades. Most developing countries as well as countries in the transition process lack their own (domestic) capital. By attracting FDI, as an additional source of financing, these countries can successfully change economic structure and adapt to the requirements of the world market.

Due to the lack of its own capital, the Republic of Serbia needs foreign capital too, primarily in the form of FDI. FDI is expected to encourage restructuring of the economy, increase exports, as well as economic growth and development. Until the growth of domestic investment is achieved, FDI will be the primary production driver, primarily referring to production aimed at foreign markets.

The government of the Republic of Serbia has to work even further in the coming period to attract FDI, which will contribute to export growth, without increasing its indebtedness to foreign countries. Increasing the FDI inflow increases the chances of transferring modern technology from abroad, brings employment growth, increases export and, consequently, economic growth and development of the Republic of Serbia.

In order to demonstrate the FDI impact on economic growth and development as well as the export growth of the Republic of Serbia, we will first present the characteristics of global FDI flows. We will try to identify the importance of FDI for GDP growth. Then we will show the real short-term and long-term effects of FDI. Finally, we will present the effects of FDI on export of the Republic of Serbia.

\section{Foreign direct investment as a global phenomenon}

Foreign direct investment is a complex phenomenon, with a decisive influence on the economic development of each country. In addition to its economic effects, FDI exerts different social, political, and technological impacts. Although strong competition coming with foreign investors prevents growth and development of the domestic economy to keep it easier in colonial slavery, these investors become an increasingly powerful factor in society, as opposed to the state. Under such conditions, FDI cannot be a fundamental factor in the sustainable development of the national economy.

FDI today mostly occurs in underdeveloped and transition countries. This is mainly investment with a low level of technological intensity, which these countries accept because of insufficient domestic accumulation and high unemployment. In contrast, developed countries mainly exchange FDI in the field of high technology, which is a requirement for the production of technologically sophisticated and globally competitive products. Over the past three decades, FDI has mostly been channeled through transnational corporations, and, therefore, can be considered as the main carrier of the globalization process.

Although the global economic crisis has significantly contributed to the global reduction in FDI, it remains a key instrument through which national economies encourage production, import know-how, develop infrastructure, increase export and employment. In addition, FDI positively impacts the payment and trade balance, as well as the collection of direct and indirect taxes. 
Globalization stimulates growth and flow of FDI between countries, primarily in the service sector where they are the most represented. Global integration of financial markets has significantly reduced FDI barriers. All these factors increase the chances of growth and development both of developed and developing countries.

Official organizations' data on the value of global FDI varies. For example, OECD experts report that in 2016 global FDI amounted to $\$ 1.613$ billion, being less by $7 \%$, compared to 2015. Nevertheless, global FDI in 2016 was higher than in some years in the period from 2009 to 2014. The share of FDI in GDP, in global terms, was $2.2 \%$ in 2007, well below the level of the global economic crisis (3.6\% of GDP) (Foreign Direct Investment Statistics: Data, Analysis and Forecasts). According to UNCTAD, due to the low growth rate of the world economy (about 2.4\%) and trade (around $1.7 \%$, the lowest level since the financial crisis) (World trade growth likely at $1.7 \%$ in 2016 : Azevedo), global FDI inflow in 2016 amounted to \$ 1.52 trillion, which is by even 13\% less than in 2015. The decline in FDI inflow was not the same in all regions and reflected the heterogeneous current impact of the economic environment on countries around the world (Global FDI Flows Slip in 2016, Modest Recovery Expected in 2017, 2017, pp. $1-7)$.

The inflow of FDI in 2016 in developing countries amounted to about $\$ 600$ billion and was down by $20 \%$, compared to 2015 , while in developed countries it reached $\$ 872$ billion and was down by about $9 \%$, compared to 2015. The lowest FDI inflow (\$52 billion) in 2016 was recorded in transition countries and increased by $38 \%$, compared to 2015. Foreign direct investment inflows to developing Asia shrank by 15 percent to \$443 billion in 2016, the first decline since 2012 (World Investment Report 2017).

FDI inflow into Europe in 2016 amounted to $\$ 385$ billion, a decrease of about $29 \%$ compared to the previous year. Some European countries recorded large fluctuations in FDI inflow. This decline was due to modest growth in investment flows in North America $(6 \%)$ and significant increase in investment in other developed countries, primarily in Australia and Japan.

The slowdown in economic growth in countries of Asia, Latin America, and the Caribbean, on the one hand, and the decline in commodity prices, on the other hand, led to a global reduction in FDI inflows in developing countries in 2016, compared to 2015, by about $20 \%$ (about $\$ 600$ billion). However, these countries continue to account for half of the 10 most important countries by FDI inflow.

In 2016, FDI inflows to transition countries increased by $38 \%$, compared to 2015 , reaching around $\$ 52$ billion, which largely reflected the increase in FDI inflows in Kazakhstan and the Russian Federation (Kazakhstan: Foreign investment). FDI in 2016 reached $\$ 20.6$ billion in Kazakhstan, which was by about $40 \%$ higher, compared to 2015. In the Russian Federation, after reaching a record level in 2013, FDI inflow rapidly diminished since 2014. This was caused by geopolitical tensions between Russia, Ukraine, and Western countries, as well as the current economic crisis in the Russian Federation itself. Thus, in 2015, the inflow of FDI into the Russian Federation decreased by $92 \%$, compared to 2014. Nevertheless, FDI inflow in 2016 increased by $62 \%$, compared to 2015 , reaching $\$ 19$ billion, mainly as a result of the privatization of the oil company Rosneft (Russia: Foreign investment). 
UNCTAD experts predict the growth of FDI in 2017 by about 10\% (Global FDI Flows Slip in 2016, Modest Recovery Expected in 2017, 2017, pp. 1-7), but it is quite uncertain. One should expect faster growth of the world economy and the volume of global trade. Economic activity in developed countries, on the one hand, and between emerging economies and developing countries, on the other hand, should encourage investment activities. However, differences between countries in terms of economic development and the presence of uncertainty in the implementation of economic policy can significantly limit such activities.

\section{Characteristics of FDI in the Republic of Serbia in the period from 2006 to 2016}

Net FDI is very important for the economic development of the Republic of Serbia. To prove this, we will first analyze the relationship between net FDI and real GDP growth over the eleven-year period (2006 to 2016), and then the distribution of FDI by sector.

Net FDI in the Republic of Serbia in the period from 2006 to 2016 amounted to $€ 16.939$ billion (see Table 1). Due to the accelerated process of privatization of social and state enterprises in the period from 2006 to 2009, net FDI of $€ 8.340$ billion was recorded, which is $49.23 \%$ of all net FDI in the Republic of Serbia in the period from 2006 to 2016. Nevertheless, the total amount of net FDI in the Republic of Serbia in this period was significantly lower than in more developed transition economies. The problem is also that FDI occurred mainly in the sector of non-tradable goods - telecommunications, banking, insurance, energy, real estate, and retail. Distributed in this way, FDI can also cause negative consequences if it does not generate foreign exchange inflows.

Growth of net FDI, as a rule, should contribute to real GDP growth or a decrease in oscillation rates of real GDP growth. In the period from 2006 to 2008, the average annual real GDP growth rate was $5.4 \%$, while the average annual growth rate of net FDI was $40.2 \%$. Nevertheless, in the period from 2009 to 2016, the average real GDP growth rate was significantly lower $(0.3 \%)$ than the average growth rate of net FDI $(36.4 \%)$.

Table 1 FDI and GDP trends in the period from 2006 to 2016

\begin{tabular}{|c|c|c|c|c|c|}
\hline Years & $\begin{array}{c}\text { Net FDI } \\
(\text { in } 000000 €)\end{array}$ & $\begin{array}{c}G D P \\
(\text { in } 000000 €)\end{array}$ & $\begin{array}{c}\text { Real GDP growth } \\
\text { (in \%) }\end{array}$ & $\begin{array}{c}\text { Net FDI growth } \\
\text { (in \%) }\end{array}$ & $\begin{array}{c}F D I / G D P \\
(\text { in } \%)\end{array}$ \\
\hline 2006 & 3.323 & 24.435 & 4,9 & 165,84 & 13,6 \\
\hline 2007 & 1.821 & 29.452 & 5,9 & $-45,20$ & 8,6 \\
\hline 2008 & 1.824 & 33.705 & 5,4 & 0,20 & 7,4 \\
\hline 2009 & 1.372 & 30.655 & $-3,1$ & $-24,77$ & 6,7 \\
\hline 2010 & 860 & 29.766 & 0,6 & $-37,33$ & 3,8 \\
\hline 2011 & 1.827 & 33.424 & 1,4 & 112,40 & 9,9 \\
\hline 2012 & 242 & 31.683 & $-1,0$ & $-86,76$ & 2,4 \\
\hline 2013 & 769 & 34.263 & 2,6 & 217,75 & 3,8 \\
\hline 2014 & 1.236 & 33.319 & $-1,8$ & 60,86 & 3,7 \\
\hline 2015 & 1.804 & 33.491 & 0,7 & 45,90 & 5,4 \\
\hline 2016 & 1.861 & 34.098 & 2,8 & 3,10 & 5,5 \\
\hline Total & 16.939 & & & & \\
\hline
\end{tabular}


Source: Data for the period from 2006 to 2015 taken from: Public Finances Bulletin, (2016) 148 (12), Belgrade: Ministry of Finance, pp. 16-18. Data for 2016 taken from: "Economic activity. Job market. Balance of Payments and Foreign Trade". (2016) Quarterly Monitor of Economic Trends and Policies in Serbia, No. 47 (10-12), Belgrade: Foundation for the Advancement of Economics, pp. 11-29.

The total inflow of net FDI in the period 2013-2016 amounted to $€ 5.670$ billion. The increase in net FDI inflows in 2014, 2015, and 2016 was the result of a gradual recovery of the world economy, especially the eurozone economy, as well as strong stimulating economic policy measures.

Data in Table 1 provides an opportunity to analyze the relationship between the relative real GDP growth and the relative net FDI growth in the sixteen-year period. The results of the analysis are the following:

- In 2006, there were high real GDP growth rates and net FDI growth, compared to 2005 ;

- GDP in real terms increased by $1 \%$ (from 4.9 to $5.9 \%$ ) in 2007, compared to 2006, while net FDI declined by $45.2 \%$, compared to net FDI in the previous year;

- In 2008, there was a mild fall in real GDP in relation to the previous year (from $5.9 \%$ in 2007 to $5.4 \%$ in 2008), but also a rise in net FDI by $0.2 \%$ relative to the level of net FDI in 2007;

- $\quad$ Real GDP decline of 3.1\% was registered in 2009, while net FDI dropped by even $24.77 \%$, compared to the level of net FDI in 2008.

In the period from 2010 to 2016, there were drastic net FDI fluctuations (growth and fall), as well as slight fluctuations in the trend (real growth and real fall) of GDP.

Data in Table 1 shows that, in certain periods, there was a rise in net FDI and real GDP growth. However, real GDP growth rates did not follow net FDI rates. Real GDP growth was based on increased consumption, generated from realized privatization revenues.

FDI inflow into the Republic of Serbia in 2016 amounted to $€ 1.861$ billion. However, foreign companies took about $€ 1.4$ billion from the Republic of Serbia in 2016. Approximately $€ 700$ million were taken out of the country untaxed under the so-called intercompany borrowings. This is due to the inadequate taxation of foreign investors and other benefits offered to them. Some investors get large subsidies, avoid paying tax on profits, limit workers' rights, and pay low salaries. In addition, some foreign companies give loans to their branches in the Republic of Serbia. Although the investment model in the form of loans is represented in international business, it is not always entirely justified. It is arguable whether loan can be treated as investment, because it must be repaid (with interest).

Government investment is now about 3\% of GDP, while domestic investment is $10 \%$ of GDP and, together with foreign investment, accounts for around $15 \%$ of GDP. Both public and private investment is now less than it should be. In the structure of total investment, FDI share is relatively high - over $5.5 \%$ of GDP or about $30 \%$ of total investment. To achieve high economic growth rates, domestic private investment should increase to around $15 \%$ of GDP, government to $4-5 \%$ of GDP, while FDI should continue 
to be over 5\% of GDP. With this, the Republic of Serbia would approach the desired level of total investment of $25 \%$ of GDP, where investment in infrastructure would be a key factor in accelerating economic growth and development.

The Government of the Republic of Serbia must constantly work to strengthen macroeconomic stability and improve the investment environment so that foreign investors are motivated to invest even without large state subsidies. If there is macroeconomic stability and legal certainty in the country, citizens are more willing to save in order to spend more in the future. This is indicated by the experience of Bulgaria, where domestic savings rate is about $25 \%$ of GDP. Bulgaria's growth is similar to the growth of the Republic of Serbia, but Bulgaria's growth is more sustainable because it relies more on country's own resources. The Republic of Serbia still largely finances projects with foreign funds, which can cause major problems in the balance of payments in the future.

In order to recognize the real effects of FDI in the Republic of Serbia, it is necessary to identify the ways in which foreign companies take profit abroad and return it to their central offices. Taking profit is legal when foreign companies pay dividends to owners. However, there is also a matter of illegal profit taking. Foreign companies achieve this by "inflating" the prices of import materials, which reduces their profit in the Republic of Serbia. Regardless of the fact that this problem has existed for several years and that contracts have been terminated with many foreign investors, the attitudes of Serbian state authorities towards these investors have not changed. For example, even two thirds of the total subsidies have been given to foreign investors, which is why the indebtedness of our country has increased by about $€ 165$ million.

The real effects of FDI should not be overestimated. In the long run, in addition to numerous benefits, FDI also has some consequences. Therefore, the final evaluation of the benefits that the FDI provides to the Republic of Serbia should not be linked for a period of 3 to 5 years, but for a period of 15 to 20 years. Since foreign investors do not stay in the Republic of Serbia for too long, it is difficult to identify the total real effects of their investment.

\section{Contribution of FDI to Serbian export}

Thanks to FDI, the Republic of Serbia has improved the technological structure of export in the last decade. Although the share of commodities of lower processing phases in total export is still high, export has increased significantly to countries from which large FDI inflows came, such as Italy and Germany, primarily referring to products from newly-founded companies.

The inflow of FDI into the Republic of Serbia by 2008 mainly focused on the purchase of local monopolies (or oligopolies) in the fields of finance, retail trade, energy products, cement and cigarette production, which had a negative effect on its balance of payments. After that, there was an increase in investment into more sophisticated production capacities, primarily due to the arrival of companies such as: FIAT, Jura, Panasonic, and Ball Packaging. This confirmed the rule, which is often encountered in economic literature and business practice, that FDI contributes to export only if there is an absorption capacity for the application of advanced technology. In the Republic 
of Serbia, since the crisis, the focus has shifted to attracting FDI in the manufacturing industry. There are tax incentives when hiring new workers, as well as a free offer of infrastructure necessary for the operation of the company, reflected in technological parks. It is encouraging that the share of FDI in industry in recent years was almost two fifths on average, which is twice the average for the first decade of the $21^{\text {st }}$ century (Nikolić, 2017, pp. 137-138).

Table 2 shows a comparative overview of the growth of exports of goods and services in the GDP of the Republic of Serbia and selected countries. It is evident that the Republic of Serbia has made significant progress as it increased the share of its exports of goods and services in GDP from 32.9\% in 2010 to 50.9\% in 2016. In 2016, the Republic of Serbia managed to achieve a higher share of exports of goods and services in GDP, compared to almost all Western Balkan countries. Exports of goods and services grew in the observed period mainly due to the recovery of global demand, especially in the countries of the European Union, which are the largest export markets of companies from the Republic of Serbia. Nevertheless, compared to Bulgaria, and especially the Czech Republic, the Slovak Republic, and Hungary, the Republic of Serbia is still significantly lagging behind them, judging by the value of the observed indicator. Over $50 \%$ of Serbian export is realized on the EU market (Krstić, Stanišić, Stojanović, p. 359).

Table 2. Share of exports of goods and services in \% of GDP

\begin{tabular}{|l|c|c|c|c|c|c|c|}
\hline & $\mathbf{2 0 1 0}$ & $\mathbf{2 0 1 1}$ & $\mathbf{2 0 1 2}$ & $\mathbf{2 0 1 3}$ & $\mathbf{2 0 1 4}$ & $\mathbf{2 0 1 5}$ & $\mathbf{2 0 1 6}$ \\
\hline Albania & 32,4 & 34,0 & 33,4 & 35,5 & 28,2 & 27,3 & 28,7 \\
\hline B\&H & 29,7 & 32,1 & 32,4 & 33,8 & 34,1 & 34,6 & $/$ \\
\hline Bulgaria & 50,2 & 59,1 & 60,8 & 64,7 & 65,0 & 64,1 & 63,6 \\
\hline Montenegro & 37,0 & 42,3 & 43,7 & 41,3 & 40,1 & 42,5 & 42,2 \\
\hline Czech Republic & 66,2 & 71,3 & 76,2 & 76,9 & 82,6 & 83,0 & 80,3 \\
\hline Croatia & 37,7 & 40,4 & 41,6 & 43,0 & 46,4 & 50,0 & 51,4 \\
\hline Macedonia & 39,8 & 47,1 & 45,3 & 43,4 & 47,7 & 48,8 & 49,2 \\
\hline Hungary & 82,2 & 87,2 & 86,8 & 86,0 & 88,7 & 90,7 & 92,5 \\
\hline Republic of Slovakia & 76,3 & 85,0 & 91,4 & 93,8 & 91,8 & 93,5 & 93,8 \\
\hline Republic of Serbia & $\mathbf{3 2 , 9}$ & $\mathbf{3 4 , 0}$ & $\mathbf{3 6 , 9}$ & $\mathbf{4 1 , 2}$ & $\mathbf{4 3 , 4}$ & $\mathbf{4 6 , 7}$ & $\mathbf{5 0 , 9}$ \\
\hline
\end{tabular}

Source: https://data.worldbank.org/indicator/NE.EXP.GNFS.ZS.

Table 3 gives a comparative analysis of the relative share of net FDI in GDP. In the period from 2013 to 2015, the relative share of FDI in the GDP of the Republic of Serbia was low, compared to most of the countries observed. The reasons are the following: unstable political situation, frequent elections, government reconstruction, and high budget deficit and public debt. All this gave investors an indication of an unstable environment. During 2015 and 2016, there was a slight increase in the relative share of net FDI in GDP. This increased chances of GDP growth and expors of the Republic of Serbia. 
Table 3. Share of net FDI in \% in GDP

\begin{tabular}{|l|c|c|c|c|c|c|}
\hline $\begin{array}{l}|c| \\
\text { Yountries }\end{array}$ & $\mathbf{2 0 1 2}$ & $\mathbf{2 0 1 3}$ & $\mathbf{2 0 1 4}$ & $\mathbf{2 0 1 5}$ & $\mathbf{2 0 1 6}$ & $\begin{array}{c}\text { Average } \\
\mathbf{2 0 1 2 - 2 0 1 6}\end{array}$ \\
\hline Albania & 7,5 & 9,8 & 8,7 & 8,7 & 9,2 & 8,8 \\
\hline B\&H & 2,3 & 1,7 & 2,8 & 1,8 & 1,6 & 2,0 \\
\hline Bulgaria & 3,3 & 3,6 & 3,6 & 5,5 & 2,4 & 3,7 \\
\hline Montenegro & 15,2 & 10,0 & 10,8 & 17,4 & 5,4 & 11,8 \\
\hline Czech Republic & 4,5 & 3,5 & 3,9 & 0,9 & 3,4 & 3,2 \\
\hline Croatia & 2,6 & 1,6 & 6,9 & 0,3 & 1,9 & 2,7 \\
\hline Macedonia & 3,5 & 3,7 & 0,5 & 3,0 & 5,3 & 3,2 \\
\hline Hungary & 8,3 & $-2,8$ & 9,3 & $-4,4$ & $-7,3$ & 0,6 \\
\hline Republic of Slovakia & 1,9 & 1,0 & $-0,4$ & 1,3 & 4,0 & 1,6 \\
\hline Republic of Serbia & $\mathbf{2 , 4}$ & $\mathbf{3 , 8}$ & $\mathbf{3 , 7}$ & $\mathbf{5 , 4}$ & $\mathbf{5 , 5}$ & $\mathbf{4 , 2}$ \\
\hline Source: Public
\end{tabular}

Source: Public Finance Bulletin (2017) 154 (6), Belgrade: Ministry of Finance, p. 9;

https://data.worldbank.org/indicator/BX.KLT.DINV.WD.GD.ZS?location.

In order to contribute significantly to GDP growth, the Government of the Republic of Serbia should work to increase the FDI inflow to the real sector, with selective targeting of branches that can contribute to export growth. This investment expands the possibilities for transfer of modern technology into different segments of the national economy.

In the Serbian economy sector of small and medium-sized enterprises (SMEs), plays an important role. The share of this sector in Republic of Serbia in the total number of enterprises is $99.8 \%$ and in the total number of employees $65 \%$. SMEs accounted for $54.1 \%$ of total gross value added of non-financial sector and for $43.2 \%$ of total exports of non-financial sector in 2013. Also, only 4.4\% of all Serbian SMEs recorded net income from exports. (Financing SMEs and Entrepreneurs 2016). FDI enables the integration of domestic SMEs with foreign companies. By manufacturing parts, assemblies, and subassemblies, as well as providing services for companies in developed countries, primarily in the countries of the European Union, the SMEs sector can increase commodity export of the Republic of Serbia.

The structure of net FDI in the last few years shows that most new FDI was in the manufacturing sector. The interest of the Republic of Serbia is that the future foreign investment is directed mainly to the manufacturing sector (manufacturing and construction industry), in which the tradable goods will be produced. The Government of the Republic of Serbia should continuously work to improve the investment climate, in order to increase FDI that would improve the production structure and increase international competitiveness of products.

\section{Conclusion}

In conditions of high external indebtedness of the Republic of Serbia, FDI is an important supplement to domestic sources of financing. Nevertheless, FDI in the observed period (from 2006 to 2016) did not significantly contribute to GDP growth of the Republic of Serbia. This was due to the fact that the government followed an inadequate model of transition and a very bad model of privatization. 
FDI led to the improvement of the technological base of Serbian companies, as well as to the growth of production, export, and GDP. However, before any foreign investment, the Government of the Republic of Serbia should carefully examine investors' programs and evaluate their long-term plans. By developing FDI flow control mechanisms, the government could limit foreign investors' influence on regulation and economic policy, as well as the possibility that their investment becomes an instrument of "colonization".

Unfortunately, the state authorities of the Republic of Serbia are still using state subsidies as the main tool for attracting investment. In the observed period (from 2006 to 2016), the Government offered foreign investors large subsidies, but this had little effect on economic and export growth. It has been shown that subsidies can help in a particular case, but they do not provide equal conditions for doing business for all. On the contrary, state aid attracts those investors from the labor-intensive branches, who count on cheap labor and a large volume of production, but do not bring higher capital. If money for subsidies was invested in infrastructure, roads, education, and a high-quality information system, the entire economy would benefit, business costs would be reduced, and opportunities for new investment created.

\section{References}

"Economic activity. Job market. Balance of Payments and Foreign Trade". (2016) Quarterly Monitor of Economic Trends and Policies in Serbia, No. 47 (10-12), Belgrade: Foundation for the Advancement of Economics.

Financing SMEs and Entrepreneurs 2016. (2016). An OECD Scoreboard.

Foreign Direct Investment Statistics: Data, Analysis and Forecasts. Available at: http://www.oecd.org/corporate/mne/statistics.htm. [22.05.2017]

Global FDI Flows Slip in 2016, Modest Recovery Expected in 2017. (2017) Global Investments Trend Monitor, UNCTAD, No. 25, 1(2): 1-7.

https://data.worldbank.org/indicator/BX.KLT.DINV.WD.GD.ZS?location. [19.10.2017.]

https://data.worldbank.org/indicator/NE.EXP.GNFS.ZS. [22.11.2017]

Kazakhstan: Foreign investment. Available at: https://en.portal.santandertrade.com/ establish-overseas/kazakhstan/investing. [13.06.2017]

Krstić, B., Stanišić, T., Stojanović, M. (2012) ANALYSIS OF STATE AND DEVELOPMENT FACTORS OF SMALL AND MEDIUM ENTERPRISE SECTOR IN SERBIA. FACTA UNIVERSITATIS Series: Economics and Organization 9 (3): 355-368.

Nikolić, G. (2017) Razbijanje ekonomskih mitova. Beograd: Arhipelag i Institut za evropske studije.

Public Finance Bulletin (2017) 154 (6), Belgrade: Ministry of Finance.

Public Finances Bulletin, (2016) 148 (12), Belgrade: Ministry of Finance. 
Russia: Foreign investment. Available at: https://en.portal.santandertrade.com/ establish-overseas/russia/foreign-investment. [23.05.2017]

World Investment Report 2017. (2017) UNCTAD.

World trade growth likely at $1.7 \%$ in 2016: Azevedo. Available at: http://www. thehindubusinessline.com/economy/world-trade-likely-to-grow-17-in-2016azevedo/article9531800.ece. [12.06.2017] 